\title{
Viewpoint: Range site/ecological site informa- tion requirements for classification of riverine riparian ecosystems
}

\author{
STEPHEN G. LEONARD, GEORGE J. STAIDL, KARL A. GEBHARDT, AND DONALD \\ E. PRICHARD
}

\begin{abstract}
Few ecological sites have been described sufficiently to interpret the specific functions and processes unique to riverine riparian areas. The utility of using ecological site concepts for riparian classification has also been debated due to the dynamic nature of the systems and the paucity of unaltered vegetation. We evaluated riparian sites associated with streams or rivers in 9 western states to determine the feasibility of using ecological site concepts in describing and evaluating riverine riparian ecosystems. Associated water features must be described in riparian site descriptions to establish relationships and understand "process pathways." A concept of "site progression" is proposed to differentiate between secondary succession associated with vegetation changes within a given physical environment and physical "state" changes that lead to a "new" or different potential natural plant community (i.e., a change in ecological site and secondary succession sequences). We have concluded that ecological site classification and inventory techiques utilized on uplands can be used on riparian areas with some enhancements to maintain consistency in evaluations at a "management unit" level.
\end{abstract}

Key Words: riparian classification, site progression, water features

Increased attention to riparian area values and management have generated a need for additional and more specific inventory information. Past inventory efforts to classify the vast majority of upland areas have often overlooked or at least minimized the information gathered on the small proportion of land that can be classified as riparian. Map scales appropriate for depicting upland sites relegated many of the narrow bands of riparian vegetation along small streams and rivers as "inclusions" within soil mapping units or merely identified bodies of water or streams with spot or linear symbols. The limited ecological site information existing for riparian areas can be attributed in part to the scale at which information was gathered. In accordance with the scale of observation, many sites and associated soils have not been described and the environmental factors responsible for their development have not been adequately documented.

If we assume that the increased attention to riparian areas will result in more specific inventory information at an appropriate scale, the question arises as to whether the same classification and inventory methods utilized for uplands are appropriate (Platts et al. 1987, Winward 1984). Riparian areas can undergo a great deal of change compared to uplands. Indeed, many riverine riparian sites can undergo sudden and/or extreme physical changes effected by associated stream dynamics. Furthermore, the absence of unaltered or undisturbed vegetation in most riparian areas makes the determination of climax vegetation difficult, if not impossible at times.

Investigations are a cooperative effort between the USDA, Soil Conservation Service and USDI, Bureau of Land Management.

Manuscript accepted 29 Jan. 1992.
We are assigned by the Bureau of Land Management (BLM) to evaluate the use of ecological site concepts in riparian stream systems. We were to determine if any additional information was needed to describe or interpret sites and site dynamics. Initial investigations on streams in 9 western states (Arizona, New Mexico, Wyoming, Montana, California, Idaho, Oregon, Nevada, and Colorado) indicated that site classification in the traditional range site context is an appropriate base for riparian inventory, interpretation, and evaluation. However, there are additional information requirements, particularly water information, necessary to effectively describe the environmental factors characterizing the site. In addition, processes affecting physical changes and subsequent vegetation responses must be interpreted to understand and evaluate site dynamics within the total riparian area. We have limited our observations to stream systems but recognize the need to address additional information requirements for nonstream wetland systems.

We are using the term "ecological site" as synonymous with "range site" as defined in the National Range Handbook (USDA 1976) with the provision that concepts also apply to other natural terrestrial ecosystems (USDI 1990). The term "site" will be used hereafter with indifference to agency terminology. The Soil Conservation Service (SCS), BLM, and other agencies and institutions have successfully used site classification and description as the basic component of natural resource inventories over millions of acres in the western U.S. Analysis and interpretation of inventory information requires a knowledge of physical and biological interactions and functions that affect ecological relationships and successional sequences. Traditionally, the comparison of present resource inventory information relative to site characteristics associated with the potential natural plant community of a site have proven satisfactory for management evaluations.

\section{Vegetation Succession and Site Progression}

Succession usually represents an orderly progression (in the absence of disturbance) of plant community change toward a steady state often termed the climax or "potential natural plant community". These changes in plant composition may also accompany adjustments in certain site characteristics, such as physical properties (e.g., accumulation of soil organic matter), soil chemistry, soil moisture, understory solar radiation, root distribution, populations of insects and animals, and physiognomy. The changes are often predictable because of the similar behavior of the site's environment. The ability to discern these environmental factors from one site to another is a basis for site classification. Often, the potential natural plant community is used as an indicator of these integrated environmental factors.

Neiman and Hironaka (1989) present a conceptual model (Fig. 1) of seral plant communities in 2 closely associated sites and their relationship to site specific soil units. We have substituted the term "site" for "habitat type-phase" in the illustration because Hironaka (1989) has equated the 2 as he uses them. Even in closely associated 


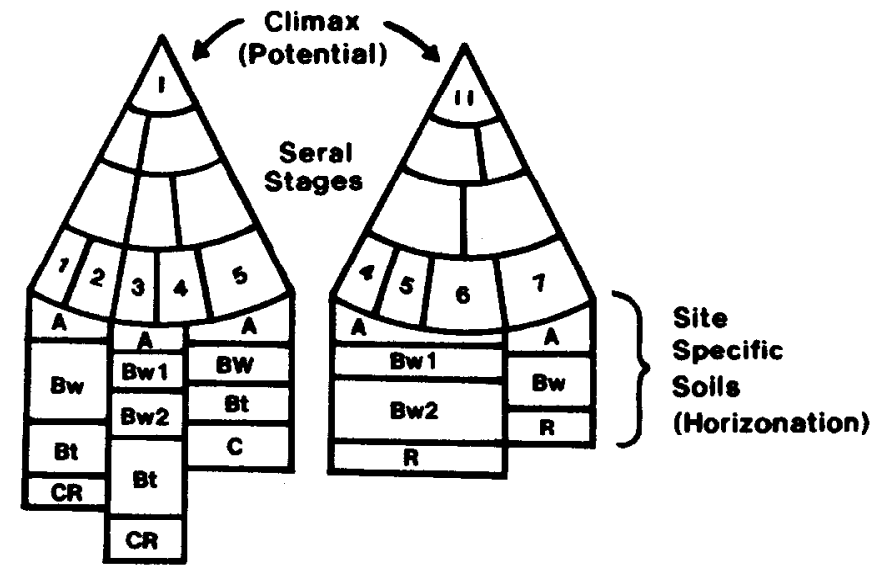

Fig. 1. Conceptual model of seral plant communities in 2 closely associated range sites and their relationship to range site specific soll units. Early seral communities 4 and 5 occur in both climax successions but occur over different soil units (Neiman, Jr., and Hironaka 1989).

upland sites, soil characteristics seldom change sufficiently to induce a change from potential I to potential II in time frames considered in most management applications. There are exceptions induced by extreme conditions such as accelerated erosion and mass wasting.

In many riparian areas, however, there is a high potential for physical environments to undergo sudden and/or extreme changes because of the potential for soil erosion, soil deposition, and changes in water availability. To help emphasize that these changes are the rule rather than the exception in riparian environments, we have introduced the term "site progression," which denotes major physical state changes within a site (Gebhardt et al. 1990). Site progression is not intended to diminish or replace any of the community succession concepts. It is a term to help those less familiar with the dynamics of riparian systems focus on the expectation for site change. Generally, site progression can be thought of as a site change which may result in a different potential natural plant community for the site (i.e., a "new" site).

The prominent factor leading to site progression is a change in soil-water status of sufficient extent as to favor a different potential natural plant community, either in kind, amount, or proportion of plants. Changes in soil-water status affect the amount, timing, and distribution of water available for plant growth and consequently the plant species that are physiologically adapted. These adjustments may be followed by modification of other soil properties such as aeration, salt accumulations, and $\mathrm{pH}$ that further affect the kinds of plants adapted. Depending on the relative stability of the site over time, changes in organic matter accumulations, nutrient status, and their affects on the potential plant community can be observed in relatively short time frames compared to upland sites.

For a classification or site description to be very useful to management, it should recognize and discuss vegetation succession, site progession, and factors that make them occur. The concept of site progression is demonstrated by Figure 2. The physical site is shown relative to its water and soil conditions. Each "state" (and related site) is connected by pathways to other possible "states" of different sites. We refer to this as "process pathways". These pathways are identified triggering mechanisms affecting the riparian site. Once the process pathways are recognized, management can better understand cause and effect relationships. Vegetation successional stages within each "state" will differ similar to the model presented in Figure 1.

Site progression and relation to soil-water status can be illustrated with 3 potential plant communities described by Kovalchik
1987). Each of these would represent a site as we are using the term and they can occur in contiguous positions. A sagebrush/cusick bluegrass (Artemisia tridentata-Artemisia cana/ Poa cusickii) potential occurs on inactive floodplains and river terraces with a water table within a depth of 2 feet of the soil surface in May and June, dropping to 4 to 5.5 feet deep in July through September. A willow/wooly sedge (Salix/Carex lanuginosa) potential can occur on adjacent active floodplains that are periodically flooded during April or May. The soil is saturated to the soil surface during this period. The water drops well down in the lower rooting zone by mid July. The third community of inflated sedge (Carex vesicaria) potential occurs on active channel shelves or other landforms within the floodplain that remain moist to saturated throughout the growing season.

As long as stream dynamics remain reasonably constant, the proportion of these sites in the riparian area will also remain quite constant even though positions may be gradually changing with natural meander migrations. However, any event or activity that changes stream dynamics and associated soil-water relations can have long-term effects on the extent of each site and their relative proportions within the riparian area.

Stream widening or incisement reduces the extent of the active floodplain by carrying more of the high flows within the channel itself. Reduced surface wetting and floodplain recharge expands the aerial extent and progression of the sagebrush/cusick bluegrass site at the expense of the other 2 sites. In cases of extreme incisement, the willow/wooly sedge and inflated sedge sites may be eliminated; they will have progressed entirely to the sagebrush/cusick bluegrass site potential. Long-term geomorphic processes are then required to reestablish site characteristics capable of supporting the wetter potential plant communities.

On the other hand, stream narrowing or blockages, such as beaver dams, induce higher water tables and promote shallow flooding and saturated soil conditions for extended periods. This condition will increase the aerial extent and relative proportion of the area capable of producing an inflated sedge potential and/or willow/wooly sedge potential depending on valley bottom morphology. Parts of the willow/wooly sedge site will have progressed (changed) to an inflated sedge site and so on.

\section{Additional Information Requirements for Individual Sites}

Closely related sites may produce similar plant communities in early seral stages (Fig. 1). Therefore, site descriptions must contain descriptions of soils and other environmental factors that adequately distinguish between each individual site's capability to produce a characteristic potential natural plant community even in the present absence of that community. Site descriptions used by the SCS and BLM identify the physiography (or landscape), climate, and soils components associated with a perceived potential natural vegetation. Contrasting conditions in 1 or more of the environmental components are used as a means of identifying the site in the absence of the original native vegetation (USDA 1976). Our observations indicate certain water features are equally important in distinguishing individual riparian sites as well as establishing relationships between groups or complexes (Winward and Padgett 1989) of sites.

The relationship to water is inherent in defining riparian areas. The interaction of both surface and ground water hydrology with other environmental factors is a dominant factor affecting site potential to produce vegetation and induce state changes.

We suggest including associated water features as a subsection of the physiography/landscape section of the site description. These relationships between stream characteristics, landscape features, and cottonwood gallery forests of Arizona have been described by Asplund and Gooch (1988) and Brady et al. (1985). Kovalchik 


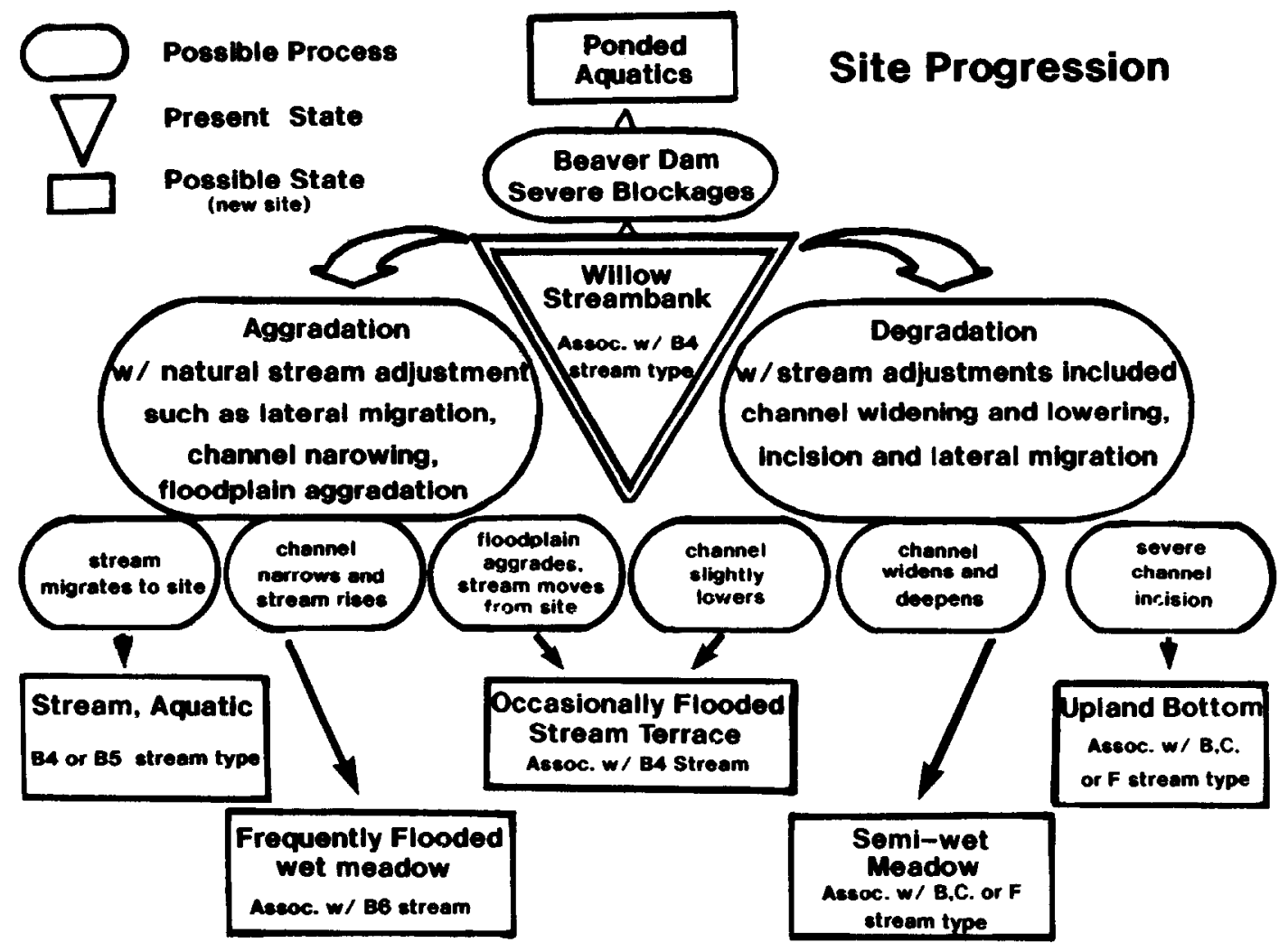

Fig. 2. Concept of site progression. The boxes represented as "States" include different sites and may be found associated with stream types (i.e., B4, B6, etc.) as described by Rosgen (1985).

(1987) has also documented potential natural vegetation associated with specific fluvial surfaces as related to soil and water characteristics in the Pacific Northwest.

Major stream type characteristics have an established relationship with geomorphic development and dynamics of adjacent landform (Leopold et al. 1964). Description can include individual morphological stream characteristics such as gradient, sinuosity, width/depth ratio, channel materials, and confinement. We have also successfully used a stream classification system described by Rosgen (1985) to characterize stream segments of similar morphology.

Flow regime and associated streamflow discharge characteristics influence the distribution of plant communities in relation to frequency, intensity, and duration of flooding (Harris et al. 1985). General flow regime (ephemeral, perennial, etc.) (Lowe et al. 1986) in association with seasonal position of the water column (Fenner et al. 1985) and probability of extreme flow events over time (1-, 5-, 10-year events, etc.) can be used to evaluate these relationships. Flooding frequency, duration, and timing should also be documented in relation to landscape features, soil properties, and interpretative values for plant growth (USDA 1983).

Drainage area and stream size are related to the streamflow discharge characteristics described above. Drainage area has also been directly correlated with site characteristics in west-central Arizona (Asplund and Gooch 1988).

Special modifiers such as organic debris (Heede 1985), presence and frequency of beaver dams (Parker et al. 1985), depositional and adjustment features, or other modifiers are often needed to characterize a site and evaluate possible state changes.

Ground water factors (Groeneveld and Griepentrog 1985), including system extent, source type, and recharge or loss characteristics, can provide information to evaluate spatial relationships with adjoining landscapes as well as characterizing individual sites.

Water table characteristics (USDA 1983) should be described in relation to kind, depth, and timing. This can be related to a description of the annual pattern of soil-water states that provides a monthly distribution of soil moisture available at incremented depths for plant growth (USDA 1981).

Site interpretations include the potential importance of the site for major uses such as grazing, wildlife habitat, and recreation. Because secondary succession and site progression are often associated with and affected by use and management, we suggest that these processes be described in the site interpretations.

Common patterns of retrogression have been broadly discussed in relation to increaser, decreaser, and invader species associated with common perturbations of the site (grazing and fire) and range condition class. We suggest that a presentation of present vegetation community types would provide several benefits.

Presentation of known successional community types helps users recognize processes associated with secondary succession and changes that may be leading toward site progression. Kovalchik (1987) and Hansen et al. (1989) describe community types such as Kentucky bluegrass (Poa pratensis) as an indication of drying conditions that may change site potential on some sites.

There are many ongoing riparian inventories using other classifications based on either present vegetation characteristics (Winward 1984) or present and potential (climax) vegetation characteristics (Hansen et al. 1988, Swanson et al. 1988, Kovalchik 1987) in association with other environmental factors. Description of successional community types allows comparison with other classifications for technology transfer.

Finally, departures from climax can enhance or depreciate the value of the resultant plant community for various uses (USDA 1976). Successional community types provide insight to the vegetation attributes that actually enhance or limit particular uses or values.

Site progression processes must be sufficiently described to lead the user to a different site description based on observations or 
expectations that a site is changing or could change to a wetter or drier state. We have lumped site progression into 2 broad categories of processes associated with aggradation or degradation.

Aggradation may include natural stream adjustments such as lateral migration and can have desirable effects such as channel narrowing associated with bank building sediment deposition. Occasionally, excessive deposition can occur from accelerated upstream erosion which maintains site progression in a dynamic state and vegetation in an early successional stage.

Degradation is generally associated with undesirable effects of channel widening and lowering or incision in more extreme cases. Degradation may also occur in natural lateral migration of stream channels.

In many stream reaches both aggradation and degradation are occuring in dynamic equilibrium, maintaining balance in the system (Heede 1986). Dynamic equilibrium infers that the balance may change with progressive development over time. Both processes must occur following disturbance of a system to restore an equilibrium. For instance, lateral erosion and redeposition of sediments can restore sinuosity and energy balance where stream channels have straightened. New balances may establish as riparian communities mature and site progression adjustments occur. We should be able to describe and understand these processes well enough to predict changes and work with, rather than against, ongoing natural adjustment processes.

\section{Discussion and Conclusion}

Site descriptions were prepared for repeatable landscape units that appeared to have a similar potential to produce vegetation along the streams investigated. Each of the associated water features described herein (most often a combination of several) was identified at one or more locations as important in either differentiating sites, identifying the site progression or both.

Our estimation of a potential natural plant community for each site described was necessarily empirical. The descriptions were based on limited data collection, observations, existing data, and literature to evaluate the overall concept. In application, the determination is based on more extensive documentation of vegetation communities occurring on the site over a larger geographic area.

For management considerations, we agree with Winward and Padgett (1989) in that we are generally working with communities that are not necessarily endpoints in succession. This does not necessarily prevent us from relating successional sequences and classifying sites based on potential vegetation to the best of our knowledge. Site descriptions should not be static. Descriptions can and should be updated as new information and research indicates a need to do so.

Site progression was apparent on most streams evaluated and processes could be described based on observations and existing data. The interpretation of these processes at individual locations, however, appears to be specific to the group of sites present. Spacial and temporal relationships between associated water features and adjacent landforms appear to influence the extent, distribution, and dynamics of sites present as well as the particular group along any one stream segment. Soil survey map unit concepts were employed to describe and interpret these groups or complexes of sites.

Soils and sites are correlated during the soil survey process; therefore, spacial presentation of site information can be portrayed in traditional map unit design. However, the soils and associated sites must be identified as major components of a map unit to maintain a record of specific attributes rather than merely being identified as inclusions.

Map scale determines the smallest size unit that can be practi- cally delineated on a map. Maps or photos with scales of $1: 2,000$ to 1:4,000 are necessary on many riparian areas (Ohmart and Anderson 1986 , Jensen et al. 1989) to identify single component units and even then may require some multi-component units. Maps at this scale become a point in time reference and can be expected to change with site progression. While this change may be precisely what the study is intended to show, the detail may be overwhelming for more general evaluations.

Multi-component map units, designed properly, can provide a longer term interpretative unit more conducive to analysis in relation to adjacent uplands. If we consider stream segments of similar stream morphology (Rosgen 1985) and similar valley bottom geomorphology, there are groups of sites that repeatedly occur in that situation over a wide geographic area of similar climate, etc. Although we are suggesting soil map units correlated with sites, the concept is the same as riparian complexes described by Winward and Padgett (1989). The geographic position of an individual site may change with fluvial processes. The group of sites and their relationship with associated water features and landscape components will remain reasonably constant for longer periods.

Similar stream segments can, in effect, become riparian map units at map scales consistent with upland mapping $(1: 24,000)$. Current cartographic guidance (USDA 1983) doesn't allow for line segments as map units, thereby eliminating the opportunity to identify the component soils at the series or family levels and their correlated sites. Allowance of line segment map units, supplemented with larger scale maps to determine land area if necessary, would provide a permanent source of riparian information in soil and plant data bases. We also have to realize that riparian map units may still change if stream balance and adjustment processes eventually lead to a different stream type. The original map unit will still provide the necessary resource information base for corrective actions.

We have concluded that site classification and inventory techniques in the context of range sites (SCS) and ecological sites (BLM) can be used on riparian areas if special attention is given to hydrology, site dynamics, and map unit design. We have provided these recommendations to the agencies and anticipate field trials in the near future. Field application will determine whether the enhanced techniques can be used on riparian sites as well as uplands.

\section{Literature Cited}

Asplund, K.K., and M.T. Gooch. 1988. Geomorphology and distribution ecology of Fremont cottonwood (Populus fremontii) in a desert riprian canyon. Desert Plants 9:17-27.

Brady, W., D.R. Patton, and J. Paxson. 1985. The development of southwestern riparian gallery forests. p. 39-43. In: Johnson, R. Roy, Charles D. Ziebell, David R. Patton, Peter F. Folliott, R.H. Hamre (tech. coords.). Proc. Riparian ecosystems and their management. Reconciling Conflicting Uses Conference. 16-18 April, Tucson, Ariz. USDA, Forest Serv. Gen. Tech. Rep. RM-120.

Fenner, P., W.W. Brady, and D.R. Patton. 1985. Effects of regulated water flows on regeneration of Fremont cottonwood. J. Range Manage. 38:135-138.

Gebhardt, Karl, Steve Leonard, George Staidl, and Don Prichard. 1990. Riparian and wetland classification review. TR 1737-5. USDI, Bureau of Land Management, Service Center, Denver, Colo.

Groeneveld, D.P., and T.E. Griepentrog. 1985. Interdependence of groundwater, riparian vegetation, and streambank stability: a case study. p. 44-48. In: Johnson, R. Roy, Charles d. Ziebell, David R. Patton, Peter F. Folliott, R.H. Hamre (tech. coords.) Proc. Riparian ecosystems and their management. Reconciling Conflicting Uses Conference. 16-18 Apr. Tucson, Ariz., USDA, Forest Serv. Gen. Tech. Rep. RM-120.

Hansen, P., S. Chadde, R. Pfister, J. Joy, D. Svoboda, J. Pierce, and L. Myers. 1988. Riparian site types, habitat types, and community types of southwestern Montana, draft version 1. Montana Riparian Assoc., School of Forestry, Univ. Montana. Missoula. 
Harris, R.R., R.J. Risser, and C.A. Fox. 1985. A method for evaluating streamflow discharge-plant species occurrence patterns on headwater streams. p. 87-90. In: Johnson, R. Roy, Charles D. Ziebell, David R. Patton, Peter F. Folliott, R.H. Hamre (tech. coords.). Proc. Riparian ecosystems and their management. Reconciling Conflicting Uses Conference. 16-18 Apr. Tucson, Ariz. USDA, Forest Serv. Gen. Tech. Rep. RM-120.

Heede, B.H. 1985. Interactions between streamside vegetation and stream dynamics. p. 54-58. In: Johnson, R. Roy, Charles D. Ziebelle, David R. Patton, Peter F. Folliott, R.H. Hamre (tech. coords.). Proc. Riparian ecosystems and their management. Reconciling Conflicting Uses Conferences. 16-18 Apr. Tucson, Ariz. USDA, Forest Serv. Gen. Tech. Rep. RM-120.

Heede, B.H. 1986. Balance and adjustment processes in stream and riparian systems. p 3-7. In: Proc. Wyoming Water 1986 and Streamside Zone Conference, Wyoming Water Research Center, U.W. Agr. Ext. Serv., Univ. Wyoming.

Hironaka, M. 1989. Relationship of habitat type and range site. p. 300-301. In: Ferguson, Dennis E., Penelope Morgon, Fredrick D. Johnson (compilers). Proc. Land Classification Based on Vegetation: Applications for Resource Management. USDA, Forest Serv. Gen. Tech. Rep. INT-257.

Jensen, S., R. Ryel, and W.S. Platts. 1989. Pilot study, classification of riverine/riparian habitat and assessment of nonpoint source impacts, North Fork Humboldt River, Nevada. White Horse Associates. Smithfield, Ut.

Kovalchik, B.L. 1987. Riparian zone associations-Deschutes, Ochoco, Fremont, and Winema National Forests. USDA Forest Serv. Region 6 Ecology Tech. Paper 279-87.

Leopold, L.B., M.G. Wolman, and J.P. Miller. 1964. Fluvial processes in geomorphology. Freeman, San Francisco, Calif.

Lowe, C.H., R.R. Johnson, and P.S. Bennett. 1986. Riparian lands are wetlands: the problem of applying eastern American concepts and criteria to environments in the North American Southwest. p. 119-122. In Vol. 16, Hydrology and water resources in Arizona and the Southwest. Proc. 1986 meetings of the Arizona section-American Water Resource Assoc., Hydrology section-Ariz.-Nev. Acad. of Sci. and the Ariz. Hydro. Soc. 19 April. Glendale, Ariz.

Neiman, K.E., Jr., and M. Hironaka. 1989. Soil-habitat type relationships: a theoretical model. p. 193-196. In: Ferguson, Dennis E., Penelope Morgon, Fredrick D. Johnson (compilers). Proc. Land Classification Based on Vegetation: Applications for Resource Management. USDA Forest Serv. Gen. Tech. Rep. INT-257. USDA, Forest Serv., Intermountain Res. Sta.
Ohmart, R.D., and B.W. Anderson. 1986. Riparian habitat. p. 169-199. In: Cooperrider, A.Y., R.J. Boyd and H.R. Stuart (eds.). Inventory and monitoring of wildlife habitat. USDI, Bur. Land Manage., Service Center, Denver, Colo.

Parker, M., F.J. Wood, Jr., B.H. Smith, and R.G. Elder. 1985. Erosional downcutting in lower order riparian ecosystems: have historical changes been caused by removal of beaver? p. 35-38. In: Johnson, R. Roy, Charles D. Ziebell, David R. Patton, Peter F. Folliott, R.H. Hamre (tech. coords.). Proc. Riparian ecosystems and their management. Reconciling Conflicting Uses Conferences. 16-18 Apr., Tucson, Ariz. USDA, Forest Serv. Gen. Tech. Rep. RM-120.

Platts, William S., Carl Armour, Gordon D. Booth, Mason Bryant, Judith L. Bufford, Paul Cuplin, Sherman Jensen, George W. Lienkemper, G. Wayne Minshall, Stephen B. Monson, Rodger L. Nelson, James R. Sedell, Joel S. Tuhy. 1987. Methods for evaluating riparian habitats with applications to management. USDA Forest Serv. Gen. Tech. Rep. INT-221.

Rosgen, D.L. 1985. A stream classification system. p. 91-95. In: Johnson, R. Roy, Charles D. Ziebell, David R. Patton, Peter F. Folliott, R.H. Hamre (tech. coords.). Proc. Riparian ecosystems and their management. Reconciling Conflicting Uses Conference. 16-18 Apr. Tucson, Ariz. USDA, Forest Serv. Gen. Tech. Rep. RM-120.

Swanson, S., Ray Miles, S. Leonard, and K. Genz. 1988. Classifying rangeland riparian areas: the Nevada task force approach. J. Soil and Water Conserv. 43:259-263.

USDA. 1976. National range handbook. Soil Conserv. Serv. Washington, D.C.

USDA. 1981. Revised soil survey manual. Soil Conserv. Serv. Washington, D.C.

USDA. 1983. National soil handbook. Soil Conserv. Serv. Washington, D.C.

USDI. 1990. National range handbook Notice-1. Manual handbook H4410-1. Bur. Land Manage. Washington, D.C.

Winward, A.H. 1984. An ecosystem classification for Intermountain riparian areas. p. 1-5. In: Proc. 1984 Pacific Northwest Range Management Short Course, Range Watersheds, Riparian Zones and Economics: Interrelationships in Management and Use. Oregon State Univ., Corvallis.

Winward, A.H., and W.G. Padgett. 1989. Special considerations when classifying riparian areas. p. 176-179. In: Ferguson, Dennis E. Penelope Morgon, Fredrick D. Johnson (compilers). Proc. Land Classifications Based on Vegetation: Applications for Resource Management. USDA Forest Serv. Gen. Tech. Rep. INT-257. 